\title{
Short communication: The first report of Cyberlindnera rhodanensis associated with clinical bovine mastitis
}

\author{
Felipe Morales Dalanezi, ${ }^{*}$ Giselle Souza da Paz, ${ }^{*}$ Sâmea Fernandes Joaquim, ${ }^{*}$ Felipe Freitas Guimarães, \\ Sandra de Moraes Gimenes Bosco,† and Helio Langoni*1 \\ *Department of Veterinary Hygiene and Public Health, School of Veterinary Medicine and Animal Science, and \\ †Department of Microbiology and Immunology, Institute of Biosciences of Botucatu, São Paulo State University, Botucatu/SP, 18618681, Brazil
}

\begin{abstract}
An acute case of clinical mastitis in a Holstein cow from second lactation is reported here. A milk sample from the affected quarter was cultured on $5 \%$ bovine blood agar and incubated at $37^{\circ} \mathrm{C}$ for $72 \mathrm{~h}$. After 24 $\mathrm{h}$ of incubation, numerous colonies of yeast were observed: the Candida characteristic was not detected by CHROMagar Candida (Difco, Franklin Lakes, NJ). The DNA extraction of the isolate was performed, and DNA was subjected to amplification and sequencing of the D1/D2 region of the large subunit rRNA gene. The sequences were aligned using Mega 7.0 and used for searching GenBank by BLASTn (Basic Local Alignment Search Tool for nucleotides), revealing $98 \%$ of identity with Cyberlindnera rhodanensis. To date, this is the first report of this yeast associated with clinical bovine mastitis.
\end{abstract}

Key words: yeast, dairy science, milk, intramammary infection

\section{Short Communication}

Mastitis is a disease that involves, besides the multiple microbiological etiologies, many factors related to animals, landowners, milk producers, and the environment. In addition to the negative consequences for milk producers and the dairy industry, mastitis is a threat to public health because many of the causative agents can also infect humans and cause alimentary tract infections (Seegers et al., 2003; de Freitas Guimarães et al., 2013; Langoni, 2013).

Although less common, filamentous fungi and yeast can cause subclinical and clinical IMI in bovines (Victoria and Langoni, 2006). Such cases are classified as environmental mastitis because these microorganisms

Received June 20, 2017.

Accepted August 16, 2017.

${ }^{1}$ Corresponding author: hlangoni@fmvz.unesp.br are present in the environment, just as coliforms are, such as Escherichia coli (Ribeiro et al., 2006).

The research on fungal infections in both animals and humans has become more important recently, with many species of fungi previously considered nonpathogenic, both yeast and filamentous, now acting as opportunistic agents causing severe illness in immunocompromised hosts (Spanamberg et al., 2009). Surveys of mastitis caused by yeast and filamentous fungi have been reported, indicating the importance of diagnosis of such pathogens (Dworecka-Kaszak et al., 2012; Zhou et al., 2013; Ksouri et al., 2015). Researchers also report an increase in the SCC and consequently a decrease in milk yield in mastitis caused by yeast (Gaudie et al., 2009).

Microbiological examination is a key diagnostic tool because the microbiota involved in mastitis etiology vary (Watts, 1988). Characterization of mastitisassociated infectious agents enables better selection of treatment and control measures. Associated with microbiological methods, molecular techniques have also been employed with the aim to improve the diagnosis and facilitate characterization of the etiological agents of mastitis (Fadda et al., 2013; Hayashi et al., 2013; Perreten et al., 2013).

The objective of this report is to document the first case, according to the current literature, of clinical bovine mastitis associated with the yeast Cyberlindnera rhodanensis.

The farm in question is situated near the city of São Pedro (22 $32^{\prime} 55^{\prime \prime}$ S, $47^{\circ} 54^{\prime} 50^{\prime \prime}$ W, 550 m) in São Paulo state. The farm includes approximately 320 dairy cows, milked 3 times a day. The cows were kept in free stalls equipped with cross-ventilation to limit the highest indoor temperature to $20^{\circ} \mathrm{C}$ and were fed with TMR to provide the necessary nutrition for high milk production. Predipping was carried out with $0.5 \%$ iodine (Iodo Mastin Plus, DeLaval, Tumba, Sweden) for at least 1 min and $30 \mathrm{~s}$, and postdipping with $1 \%$ iodine (Della Barrie, DeLaval). The bedding type used in barns was sand, and cows left the barn only for milking. 
A milk sample was obtained from a 3-yr-old Holstein cow during second lactation, with average daily production of $47 \mathrm{~kg}$ of milk. The animal presented with acute mastitis in a single quarter; only milk alterations were reported, without systemic symptoms. The cow did not show any signs of immunosuppression or another factor that could weaken its immune system. The cow had no history of clinical mastitis, but was treated before the dry period with an appropriate antibiotic product Mastijet Vaca Seca (566 mg of benzylpenicillin G procaine, $281 \mathrm{mg}$ of benzylpenicillin $\mathrm{G}$ potassium, and 500 mg of neomycin; MSD, São Paulo, Brazil). The infected quarter was treated for $3 \mathrm{~d}$ with Mastiplan $(300 \mathrm{mg}$ of cefapirin and $20 \mathrm{mg}$ of prednisolone; MSD), and the animal did not show either clinical and bacteriological cure. Next, the affected quarter was chemically ablated (a $5 \%$ iodine solution for $2 \mathrm{~d}$ after depletion of the udder). No more cases of this yeast were observed in another cow of the herd.

Macroscopically, the milk sample contained small lumps without any other abnormalities. Each sample was cultivated on both blood bovine agar $(5 \%)$ and MacConkey agar followed by incubation at $37^{\circ} \mathrm{C}$ for 72 h. No colonies were observed on MacConkey agar. On blood agar, we observed a pure culture yielding exuberant growth of white, dry, small, nonhemolytic colonies after $24 \mathrm{~h}$. We determined the microscopic morphology using the Gram stain, resulting in visualization of gram-positive colonies with a yeast-like morphology. The colonies were transferred to a chromogenic agar (CHROMagar Candida, Difco, Franklin Lakes, NJ) and incubated at $30^{\circ} \mathrm{C}$ for $72 \mathrm{~h}$ for the presumptive identification of the yeasts; however, no colony grew in this medium.

To identify this fungus, we amplified the D1/D2 region found at the $5^{\prime}$ end of the large subunit rDNA gene using primers NL-1 (5'-GCATATCAATAAGCGGAGGAAAAG-3') and NL-4 (5'-GGTCCGTGTTTCAAGACGG-3'; O'Donnell, 1993). This region serves for identification of many genera of yeasts because it is sufficiently variable to recognize species with little nucleotide divergence (Kurtzman and Robnett, 1997; Sugita et al., 2003). The PCR was performed in a total volume of $25 \mu \mathrm{L}$ containing $10 \mathrm{mM}$ reaction buffer, Tris- $\mathrm{HCl}$ (pH 8.0), $50 \mathrm{mM} \mathrm{KCl,} 1.5 \mathrm{mM} \mathrm{MgCl}$, $0.2 \mathrm{~m} M$ deoxynucleotide triphosphates, $10 \mathrm{p} M$ of each primer, $0.5 \mathrm{U}$ of Taq Platinum polymerase (Invitrogen, Carlsbad, CA), and $10 \mathrm{ng}$ of DNA. We carried out the reaction using thermocycler Mastercycler Gradient (Eppendorf, Hamburg, Germany), and cycling conditions started with an initial denaturing step at $94^{\circ} \mathrm{C}$ for $5 \mathrm{~min}$, followed by 30 cycles at $94^{\circ} \mathrm{C}$ for $60 \mathrm{~s}, 60^{\circ} \mathrm{C}$ for $90 \mathrm{~s}$, and $72^{\circ} \mathrm{C}$ for $90 \mathrm{~s}$, and the final extension of 10 min at $72^{\circ} \mathrm{C}$.
The amplicon was subjected to sequencing, and the electropherogram thus obtained was aligned in the Mega 7.0 software (Kumar, Stecher, and Tamura, USA) and compared with sequences in GenBank (National Center for Biotechnology Information) via BLASTn (Basic Local Alignment Search Tool for nucleotides, https://blast.ncbi.nlm.nih.gov/Blast.cgi). The best match found in GenBank had a $98 \%$ identity with accession LC 177002.1.

This is the first diagnosis of $C$. rhodanensis in a bovine mastitis case, which motivated us to report the characterization of this microorganism isolated from a lacteal secretion of a mastitic mammary gland. More studies are necessary to verify the capacity of $C$. rhodanensis as a primary pathogen causing mastitis in cows; for example, an experimental assay that inoculates the yeast into the udder or the use of a cell culture should help to answer this question. Nonetheless, the objective of this article was to report a new pathogen infecting the bovine mammary gland.

Bovine mastitis caused by fungi is considerably less frequent than that caused by bacteria. The majority of cases tend to resolve spontaneously; however, sometimes the infection can become chronic and difficult to treat (Krukowski and Saba, 2003). For this reason, it is important to have an accurate diagnosis in cases of bovine mastitis and to differentiate bacterial infections from fungal infections.

Yeast are considered emergent pathogens in cases of environmental mastitis, and Candida spp. are the most frequently isolated yeasts from bovine mastitis infections (da Costa et al., 2008; Ksouri et al., 2015). The cause of infection by these pathogens is commonly attributed to the use of intramammary medicines and with hygiene problems during their application (Costa et al., 1998). Therefore, preventive methods, such as appropriate milking, handling, and proper disinfection of the equipment and facilities, need to be enforced among farmers. Decreasing the number of animals affected by this infection on farms may ensure the future quality and safety of dairy products (Spanamberg et al., 2009).

Cyberlindnera rhodanensis (teleomorph) was originally designated as Saccharomyces rhodanensis (Ramírez and Boidin, 1953) after it was isolated from products obtained after the extraction of tannins from vegetal species. According to our phylogenetic analyses, there is a divergence in the nucleotide sequence of the genes that encode the rRNA subunits and elongation factor $1 \alpha$; thus, the yeast was renamed to Lindnera rhodanensis (Kurtzman et al., 2008). In 2009, some investigators proposed to change the name to Cyberlindnera rhodanensis to avoid confusion with a similarly named species of plant (Minter, 2009). Although both names 
are accepted in the nomenclature; few researchers have studied this organism.

The combined use of molecular tools with conventional microbial techniques may facilitate the identification of a large variety of microorganisms responsible for the etiology of many diseases (Makimura et al., 1994). Molecular diagnosis contributes significantly to the identification of causative microorganisms of mastitis, in biological samples (milk or dairy products), even if another interfering microorganism is present. Causative microorganisms are difficult to detect by usual methods of microbiological culturing. Therefore, the detection of pathogens causing mastitis is becoming more efficient, thus assisting the programs of mastitis control (Phuektes et al., 2003).

Because this is an unprecedented diagnosis of C. rhodanensis associated with bovine mastitis, it highlights the importance of application of molecular tools to minimize potential mistakes in identification of yeasts when phenotype alone is used for analysis. Modern genetic techniques can yield better accuracy in the etiological analysis of bovine mastitis.

\section{ACKNOWLEDGMENTS}

This study was funded by FAPESP (The São Paulo Research Foundation, Brazil) scholarship grant number 2015/26055-1.

\section{REFERENCES}

Costa, E. O., A. R. Ribeiro, E. T. Watanabe, and P. A. Melville. 1998. Infectious bovine mastitis caused by environmental organisms. Zentralbl. Veterinarmed. B 45:65-71.

da Costa, G. M., N. da Silva, C. A. Rosa, H. C. P. de Figueiredo, and U. P. de Pereira. 2008. Mastite por leveduras em bovinos leiteiros do Sul do Estado de Minas Gerais, Brasil. Cienc. Rural 38:1938-1942.

de Freitas Guimarães, F., D. B. Nóbrega, V. B. Richini-Pereira, P. M. Marson, J. C. de Figueiredo Pantoja, and H. Langoni. 2013. Enterotoxin genes in coagulase-negative and coagulase-positive staphylococci isolated from bovine milk. J. Dairy Sci. 96:28662872 .

Dworecka-Kaszak, B., A. Krutkiewicz, D. Szopa, M. Kleczkowski, and M. Biegańska. 2012. High prevalence of Candida yeast in milk samples from cows suffering from mastitis in Poland. Sci. World J. 2012: 196347.

Fadda, M. E., M. B. Pisano, L. Scaccabarozzi, V. Mossa, M. Deplano, P. Moroni, M. Liciardi, and S. Cosentino. 2013. Use of PCR-restriction fragment length polymorphism analysis for identification of yeast species isolated from bovine intramammary infection. J. Dairy Sci. 96:7692-7697.

Gaudie, C. M., P. N. Wragg, and A. M. Barber. 2009. Outbreak of disease due to Candida krusei in a small dairy herd in the UK. Vet. Rec. 165:535-537.

Hayashi, T., T. Sugita, E. Hata, K. Katsuda, E. Zhang, Y. Kihu, K. Sugawara, T. Ozawa, T. Matsubara, T. Ando, T. Obayashi, T.
Itoh, T. Yabusaki, K. Kudo, H. Yamamoto, M. Koiwa, T. Oshida, Y. Tagawa, and K. Kawai. 2013. Molecular-based identification of yeasts isolated from bovine clinical mastitis in Japan. J. Vet. Med. Sci. 75:387-390.

Krukowski, H., and L. Saba. 2003. Bovine mycotic mastitis. (A review). Folia Vet. 47:3-7.

Ksouri, S., S. Djebir, Y. Hadef, and A. Benakhla. 2015. Survey of bovine mycotic mastitis in different mammary gland statuses in two north-eastern regions of Algeria. Mycopathologia 179:327-331.

Kurtzman, C. P., and C. J. Robnett. 1997. Identification of clinically important ascomycetous yeasts based on nucleotide divergence in the $5^{\prime}$ end of the large-subunit (26S) ribosomal DNA gene. J. Clin. Microbiol. 35:1216-1223.

Kurtzman, C. P., C. J. Robnett, and E. Basehoar-Powers. 2008. Phylogenetic relationships among species of Pichia, Issatchenkia and Williopsis determined from multigene sequence analysis, and the proposal of Barnettozyma gen. nov., Lindnera gen. nov. and Wickerhamomyces gen. nov. FEMS Yeast Res. 8:939-954.

Langoni, H. 2013. Qualidade do leite: Utopia sem um programa sério de monitoramento da ocorrência de mastite bovina. Pesqui. Vet. Bras. 33:620-626.

Makimura, K., S. Y. Murayama, and H. Yamaguchi. 1994. Detection of a wide range of medically important fungi by the polymerase chain reaction. J. Med. Microbiol. 40:358-364.

Minter, D. 2009. Cyberlindnera, a replacement name for Lindnera Kurtzman et al. nom. illegit. Mycotaxon 110:473-476.

O'Donnell, K. 1993. Fusarium and its near relatives. Pages 225-233 in The Fungal Holomorph: Mitotic, Meiotic and Pleomorphic Speciation in Fungal Systematics. D. R. Reynolds and J. W. Taylor, ed. CAB International, Wallingford, UK.

Perreten, V., A. Endimiani, A. Thomann, J. R. K. Wipf, A. Rossano, M. Bodmer, A. Raemy, K. A. Sannes-Lowery, D. J. Ecker, R. Sampath, R. A. Bonomo, and C. Washington. 2013. Evaluation of PCR electrospray-ionization mass spectrometry for rapid molecular diagnosis of bovine mastitis. J. Dairy Sci. 96:3611-3620.

Phuektes, P., G. F. Browning, G. Anderson, and P. D. Mansell. 2003. Multiplex polymerase chain reaction as a mastitis screening test for Staphylococcus aureus, Streptococcus agalactiae, Streptococcus dysgalactiae and Streptococcus uberis in bulk milk samples. J. Dairy Res. 70:149-155.

Ramírez, C., and J. Boidin. 1953. Trois nouvelles especes de levures, isolees de liqueurs tannantes. Rev. Mycol. 18:149-156.

Ribeiro, M. G., E. O. Costa, D. S. Leite, H. Langoni, F. Garino Júnior, C. Victória, and F. J. P. Listoni. 2006. Fatores de virulência em linhagens de Escherichia coli isoladas de mastite bovina. Arq Bras. Med. Vet. Zootec. 58:724-731.

Seegers, H., C. Fourichon, and F. Beaudeau. 2003. Production effects related to mastitis and mastitis economics in dairy cattle herds. Vet. Res. 34:475-491.

Spanamberg, A., E. M. C. Sanches, L. Ferreiro, and J. M. Santurio. 2009. Mastite micótica em ruminantes causada por leveduras. Cienc. Rural 39:282-290.

Sugita, T., M. Takashima, M. Kodama, R. Tsuboi, and A. Nishikawa. 2003. Description of a new yeast species, Malassezia japonica, and its detection in patients with atopic dermatitis and healthy subjects. J. Clin. Microbiol. 41:4695-4699.

Victoria, C., and H. Langoni. 2006. Occurrence of clinical and subclinical mastitis in dairy herd caused by Trichosporon beigelii. Braz. J. Vet. Res. Anim. Sci. 43:280-282.

Watts, J. L. 1988. Etiological agents of bovine mastitis. Vet. Microbiol. 16:41-66.

Zhou, Y., Y. Ren, C. Fan, H. Shao, Z. Zhang, W. Mao, C. Wei, H. Ni, Z. Zhu, X. Hou, F. Piao, and Y. Cui. 2013. Survey of mycotic mastitis in dairy cows from Heilongjiang Province, China. Trop. Anim. Health Prod. 45:1709-1714. 